OPEN ACCESS

Edited by:

Kai Wang,

Chinese Academy of Agricultural Sciences (CAAS), China

Reviewed by:

Robert Horvath

Hungarian Academy of Sciences

(MTA), Hungary

Shusong Wu,

Hunan Agricultural University, China

*Correspondence:

Yogesh Singh

ysinghbt@gmail.com;

yogesh.singh@med.uni-tuebingen.de

Specialty section:

This article was submitted to Nutritional Immunology,

a section of the journal

Frontiers in Nutrition

Received: 13 October 2020 Accepted: 17 December 2020 Published: 28 January 2021

Citation:

Singh Y, Salker MS and Lang F (2021) Green Tea Polyphenol-Sensitive

Calcium Signaling in Immune T Cell Function. Front. Nutr. 7:616934. doi: 10.3389/fnut.2020.616934

\section{Green Tea Polyphenol-Sensitive Calcium Signaling in Immune T Cell Function}

\author{
Yogesh Singh ${ }^{1 *}$, Madhuri S. Salker ${ }^{2}$ and Florian Lang ${ }^{3}$ \\ ${ }^{1}$ Institute of Medical Genetics and Applied Genomics, Eberhard Karls University, Tübingen, Germany, ${ }^{2}$ Women's Hospital, \\ Eberhard Karls University, Tübingen, Germany, ${ }^{3}$ Institute of Vegetative and Clinical Physiology, Eberhard Karls University, \\ Tübingen, Germany
}

Polyphenol compounds found in green tea have a great therapeutic potential to influence multiple human diseases including malignancy and inflammation. In this mini review, we describe effects of green tea and the most important component EGCG in malignancy and inflammation. We focus on cellular mechanisms involved in the modification of $T$ cell function by green tea polyphenol EGCG. The case is made that EGCG downregulates calcium channel activity by influencing miRNAs regulating expression of the channel at the post-transcriptional level.

Keywords: EGCG, miR-15b, T cells, SOCE, $\mathrm{Ca}^{2+}$ influx

\section{BIOLOGICAL EFFECTS AND ACTIVE COMPONENTS OF GREEN TEA}

The global consumption of tea is estimated to be 273 billion L/year, and its putative impact on health has attracted considerable scientific interest (1-3). It is believed that green tea (Camellia sinensis) was first cultivated from China and has been manufactured and used for drinking purposes for several centuries (1). Green tea is the part of Theaceae plant family that encompasses several other plants and shrubs of medicinal and ornamental interest and is chiefly consumed in East Asia, the Indian subcontinent, and Southeast Asia (4). After water, green tea is probably the second most consumed beverage worldwide $(4,5)$. Green tea has health-promoting effects in a number of pathological disorders, such as cardiovascular disease, neurodegeneration, stroke, obesity, diabetes, and viral or bacterial infections (6-8). Furthermore, due to the anti-cancer properties of green tea, its components may be used for protection against cancer (9-15).

Tea is produced in various forms due to distinct manufacturing processes (4). Green tea is produced from fresh tea leaves; however, steaming or pan-frying process is used further for enzyme deactivation, which precludes the oxidation of polyphenols termed catechins present in the tea leaves $(6,12)$. Tea mainly contains catechins that roughly contribute $30-40 \%$ in brewed desiccated green tea including (-)-epigallocatechin-3-gallate (EGCG), (-)-epigallocatechin (EGC), (-)-epicatechin gallate (ECG), and (-)-epicatechin (EC) $(5,6,12,16-19)$. EGCG is the utmost catechin available in green tea and roughly embodies $50-80 \%$ of catechins in a $200-300 \mathrm{mg} / \mathrm{brewed}$ cup of green tea (20). EGCG is the best-studied green tea component and the principal polyphenol involved in health benefiting actions such as anti-inflammatory and anti-carcinogenic effects $(12,21)$. 


\section{INFLUENCES OF EGCG AND RELATED SUBSTANCES}

Green tea and its components were already demonstrated to counteract malignancy in several animal experiments (8, 9, $11,22)$, but their biological activity in human subjects is still a matter of controversy $(12,23,24)$. EGCG has been shown to affect angiogenesis and apoptosis, and acts as an antioxidant in different types of cancer and neurodegenerative diseases $(6,14,20,25)$. However, the significance of these findings was questioned, as most of the experiments performed in these studies had used a concentration range from 20 to $200 \mu \mathrm{M}$ EGCG, which is higher than the serum concentration of EGCG encountered in humans $(<10 \mu \mathrm{M})(12)$. The EGCG concentrations in human serum or plasma can be found in a range of 0.1 and $1 \mu \mathrm{M}$ following drinking few cups of green tea and may approach $7 \mu \mathrm{M}$ with supplements $(12,13,26,27)$.

Some reports have suggested that these dietary compounds may need some modification or changes in their structure to improve the safety and effectiveness so that they can achieve their maximum bioavailability and function (28-30). Therefore, EGCG has been modified by modulation of hydroxyl groups with peracetate groups called pEGCG (prodrug of EGCG, EGCG octa-acetate) to augment the bioavailability and stability of green tea polyphenol EGCG $(12,30,31)$. The resulting polyphenolic compounds displayed enhanced anti-proliferative activity in breast cancer (12). A nanoparticle-based EGCG delivery system is already considered for oral dispensation in murine xenograft model (nude mice) with human prostate cancer (nanochemoprevention), resulting in 10 times dose advantage for pro-apoptotic and anti-angiogenic effects in vitro and in vivo (14).

The mechanism that causes the health-promoting properties of EGCG is the suppressive effect on growth of different cell types $(1,8,11-13,15,22,32-37)$. Conversely, the cell growth suppressed by EGCG is not only restricted to the tumor or cancerous cells, but it can also reduce the growth of cells that are not cancerous in nature such as bovine vascular smooth muscle cells (5). EGCG oxidizes easily and this can significantly affect its binding properties, thus impacting on cell adhesion ligand accessibility and matrix rigidity of cancer cells (38). In addition to several beneficial effects of green tea polyphenols, it can also have some potential side effects, which are summarized in recent reviews $(27,39)$. In brief, excessive consumption of green tea could lead to several side effects including dehydration (as green tea has diuretic property), deranged bile acid synthesis, gastroesophageal reflux disease and interference with iron metabolism $(4,39)$. Further research is warranted to investigate the beneficial and adverse effects of EGCG.

\section{INTERACTION BETWEEN DIETARY POLYPHENOLS AND GUT MICROBIOME}

The interaction between polyphenols including their metabolites and gut microbiota is critical to understanding the biological mechanisms of polyphenols, since polyphenols are poorly absorbed and most of them are metabolized by the microbiome to form phenolic metabolites (40). Dietary polyphenols could play a key role in growth of several beneficial bacteria including Lactobacillus and Bifidobacterium spp. by modulating the growth of other pathogenic bacteria $(41,42)$. Green tea may change the human intestinal and oral microbiota of healthy individuals (43). Two weeks of green tea liquid usage may increase the Firmicutes-to-Bacteroidetes ratio, elevate short-chain fatty acids producing genera, and reduce bacterial lipopolysaccharide (LPS) synthesis, effects maintained even after 1 week of washout period (43). In addition to this, green tea is also able to change the salivary and oral epithelium microbiota in humans $(43,44)$. Mouse studies revealed that green tea extract or its components, EGCG caffeine, and theanine, given for 7 days are also able to modulate the gut, cecum, as well as skin microbiome and metabolites following a single ultraviolet (UV) light stress $(41,45)$. The strongest effect was observed on Firmicutes-to-Bacteroidetes ratio after green tea extract, which was decreased after UV light (UV stress vs. green tea extract) (41). A human study also showed that 7 days consumption of green tea extract can lead to a change in metabolite production (46). This study highlights the important role of gut bacteria in the metabolism of green tea extract. In plasma, after $2 \mathrm{~h}$ of consumption, green tea extract was metabolized into different components ECGG, GC, and GCG and 16 out of 163 endogenous metabolites were affected including hippurate, taurine serotonin, and 3,4-dihydroxyphenylethylene-glycol (46).

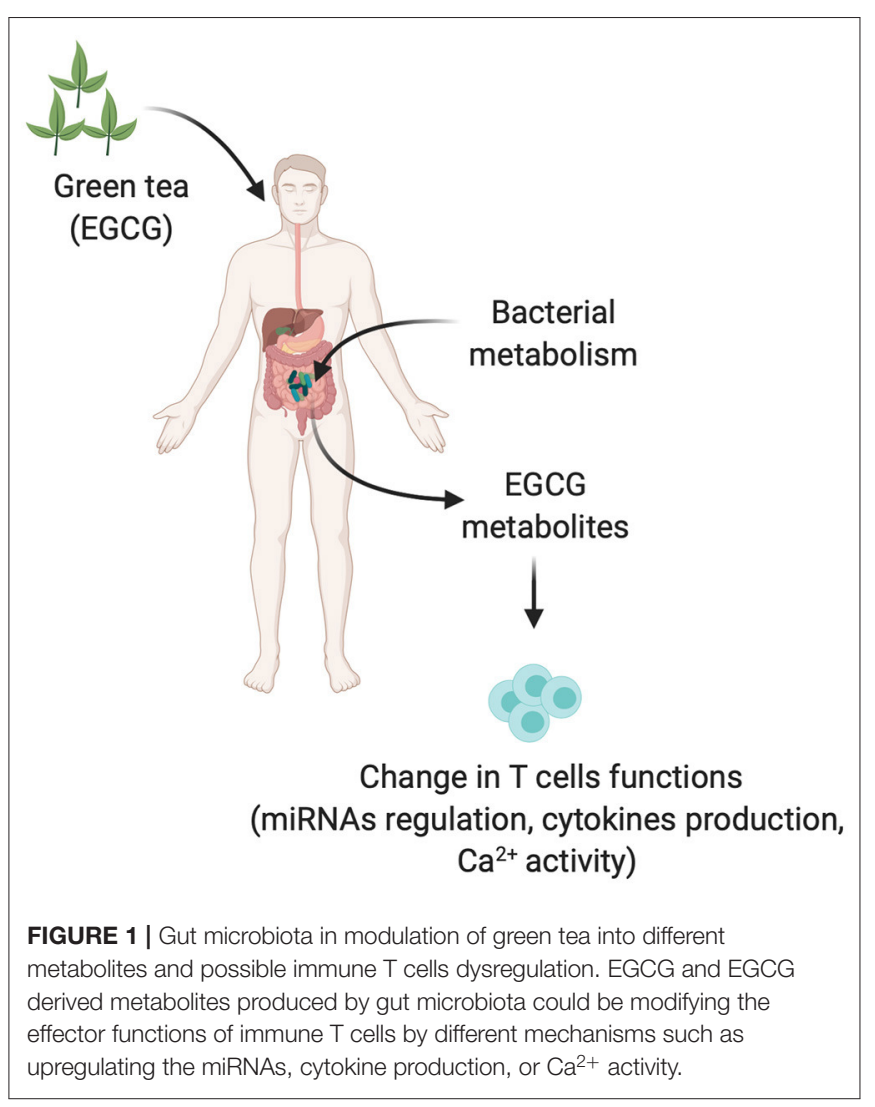


This study did not explore the change in the gut microbiota but highlights the potential role of commensals in breaking down green tea extracts. Furthermore, an in vitro study also investigated the metabolic fate of EGCG and its influence on gut microbiota and found that EGCG itself can be degraded into several metabolites (47). Microbiome profiling suggested that EGCG treatment increased the growth of several beneficial bacteria such as Bacteroides and Bifidobacterium and inhibited the growth of pathogenic bacteria Fusobacterium and Enterobacteriaceae (47). On a metabolic level, 4-phenylbutyric acid was positively or negatively correlated with 11 bacterial genera (Lachnoclostridium and Fusobacterium are positively related whereas others including Alistipes and Bacteroides are negatively correlated) (47). 4-Hydroxybenzoic acid had a negative correlation with Haemophilus bacterial genera while phenylacetic acid showed positive or negative correlation with bacterial genera (positively with Fusobacterium and negatively with Haemophilus and Streptococcus) (47). Nonetheless, animal and human reports suggest that the degradation of EGCG in the gastrointestinal tract and the function of metabolites should be considered for better understanding the mechanisms of EGCG and immune responses (Figure 1).

\section{EFFECT OF EGCG ON CALCIUM SIGNALING IN CD4+ ${ }^{+}$CELLS}

The active component of green tea is EGCG, which is able to ameliorate symptoms and diminish the pathological conditions linked with autoimmune inflammatory diseases in a number of different animal models $(1,8,20,35-37,48,49)$. Key cells involved in autoimmune disease promotion or regulation are $\mathrm{CD}^{+} \mathrm{T}$ cells and their helper subsets (50). CD4 ${ }^{+} \mathrm{T}$ helper (Th) cells perform a crucial role in adaptive immune responses (51). These Th cells employ and activate other adaptive immune cells including B cells, and CD8 T cells, as well as other cells involved in the innate immune response (52). Naïve T cells can differentiate into various effector Th cells such as Th1, Th2, Th9, Th17, Th22, T follicular helper (Tfh), and induced regulatory $\mathrm{T}$ cells (iTregs) $(49,52-63)$. These cells secrete different repertoires of cytokines and recruit various arms of the immune response $(52,58)$. Th1 and Th17 cells are entailed for protection against intracellular pathogens and fungal infections and cancers, whereas Th2 cells are required for protection against helminths (56, 64-66). Th9 and Th22 cells are less welldefined but appear to be important for airway, tumor and skin

TABLE 1 | Effects of green tea polyphenol such as EGCG and its different components on immune T cells.

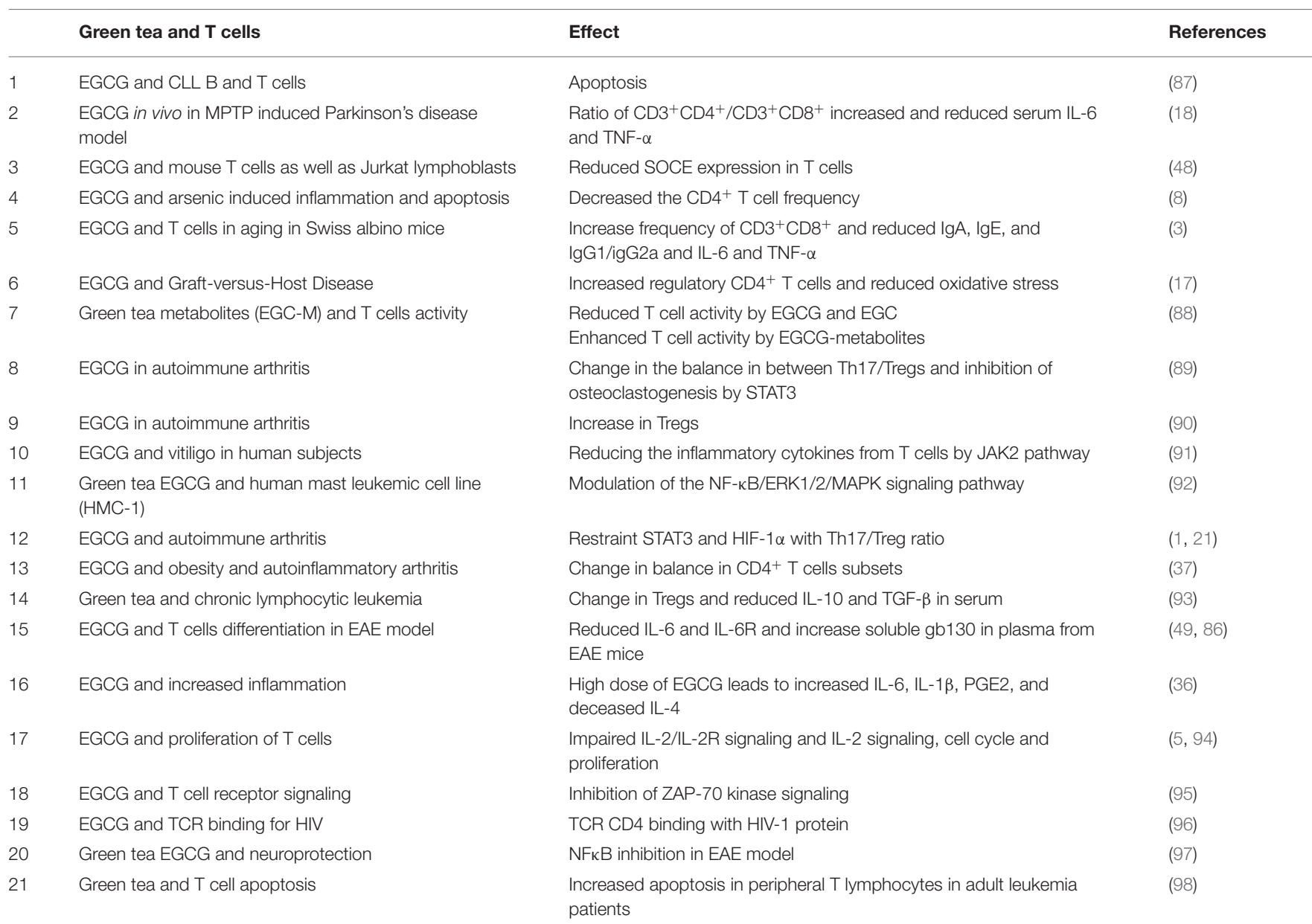


inflammation, whereas Tfh cells are vital for the activation of $B$ cells and the formation of germinal centers in secondary lymphoid organs $(52,57,61,62,67-77)$. In contrast, Tregs help to maintain immune homeostasis by suppressing the immune response and preventing reactions against host organs and autoimmunity $(51,52,78-85)$.

Recent studies demonstrated that EGCG supplemented in a diet mitigated experimental autoimmune encephalomyelitis (EAE) in a murine model, which was correlated with a lower number of Th1 and Th17 cells and an augmented number of Treg cells in the central nervous system as well as in peripheral lymphoid organs $(49,86)$. These studies also suggested that EGCG is able to inhibit inflammatory cytokines, namely, IL12 , IL-1 $\beta$, IL-6, IL-23, and TNF- $\alpha$. Furthermore, these cytokines were already proven to promote the development of Th1 (IL-12 helps in development and differentiation), Th17 (IL-1 $\beta$, IL-6, IL23-all three key cytokines promote the pathogenicity of these cells), and Th9 (TNF- $\alpha$ required for improved differentiation) cells, albeit IL-10 and IL-4 (Th2 cytokines) cytokines were not affected by EGCG $(49,86)$. Therefore, EGCG is able to modulate the $\mathrm{CD}^{+} \mathrm{T}$ cell differentiation (49). Nevertheless, further experimental support for this notion and an in-depth explanation of underlying mechanisms are desirable as Th9 cells are known to induce EAE (54) and EGCG can ameliorate EAE as described above; therefore, examining the impact of EGCG on Th9 cells in detail is required. Nonetheless, EGCG is effective against metabolic syndrome, obesity, and autoimmune arthritis by managing the fine balance of $\mathrm{CD} 4^{+} \mathrm{T}$ cells (37). The multifaced role of green tea and its different components in controlling diverse functions are summarized in Table $\mathbf{1 .}$

In several diseases, EGCG affects the outcome by modulating the function of T cells. Differential effects of EGCG are observed on the proliferation of $\mathrm{B}$ and $\mathrm{T}$ cells from $\mathrm{B}$-cell chronic lymphocytic leukemia (CLL) patients compared with healthy controls in a dose-dependent fashion (87). T or B cells are more prone to apoptosis in CLL patients compared with healthy controls (87). EGCG is shown to inhibit murine $\mathrm{CD}^{+} \mathrm{T}$ cell proliferation and induces apoptosis in vitro (Table 1) (5, $48,94)$. However, EGCG in the gut of human and mice can also be converted into different metabolites, which could exert different effects on immune $\mathrm{T}$ cell functions. Kim et al. reported that 11 EGCG metabolites have a differential effect on murine $\mathrm{CD}^{+}{ }^{+} \mathrm{T}$ cells compared with EGCG (88). EGCG and EGC green tea catechins decrease ATP levels, thus suggesting an inhibitory role in T cell activation. However, EGC metabolites (7 out of 11 metabolites) increased ATP levels compared with control and EGCG, thus reflecting activating effects on $\mathrm{T}$ cell functions (88). These results highlight the importance of gut bacteria on differential outcome of EGCG and their metabolites for regulating the functions of immune $\mathrm{T}$ cells. This could be a potential explanation why different people observe such heterogenic effects. Clearly, caution is warranted during interpretation of findings.

After engagement of the T cell receptor (TCR) with its cognate antigens leads to an activation of $\mathrm{T}$ cells, further activation triggers an increase in intracellular $\mathrm{Ca}^{2+}$ levels that is needed for the essential physiological functions of $\mathrm{T}$ cells such as gene expression, proliferation, cell motility, and cytokine production $(99,100)$. In naïve or resting $\mathrm{T}$ cells, $\mathrm{Ca}^{2+}$ accumulates in the endoplasmic reticulum (ER) of the cells and levels of $\mathrm{Ca}^{2+}$ are gauged by stromal cell-interaction proteins (STIM) 1 and 2 (101). Once TCRs are activated (after antigenic stimulation), inositol trisphosphate (IP3) is produced followed by binding to IP3 receptors expressed on the $\mathrm{ER}$ and results in the

TABLE 2 | Effects of green tea and its different componment on miRNAs expression in cancer and T cells.

\begin{tabular}{|c|c|c|c|c|}
\hline SN & Cells & Dysregulated miRNAs & Functions & References \\
\hline 1 & $\begin{array}{l}\text { Non-small-cell lung cancer (NSCLC) treated } \\
\text { with EGCG }\end{array}$ & hsa-miR-485-5p & $\begin{array}{l}\text { Inhibits cell growth and cell apoptosis } \\
\mathrm{RXR} \alpha \text { gene }\end{array}$ & (15) \\
\hline 2 & EGCG and EGC in hypertensive model & $\begin{array}{l}\operatorname{miR}-126 a-3 p \text { and } \\
\operatorname{miR}-150-5 p\end{array}$ & $\begin{array}{l}\text { Hypertension } \\
\text { SP1/AT1R pathway }\end{array}$ & $(133)$ \\
\hline 3 & $\begin{array}{l}\text { EGCG on mouse CD4 }{ }^{+} \text {T cells and human } \\
\text { Jurkat lymphoblasts }\end{array}$ & $\operatorname{miR}-15 b-5 p$ & Calcium functions-SOCE pathway & $(48)$ \\
\hline 4 & $\begin{array}{l}\text { EGCG IL-1 } \beta \text {-stimulated human osteoarthritis } \\
\text { chondrocytes }\end{array}$ & $\begin{array}{l}\text { miR-140-3p and } \\
\text { miR-199a-39 }\end{array}$ & $\begin{array}{l}\text { Anti-arthritic of EGCG by ADAMTS5 and } \\
\text { downregulation of COX2 pathway }\end{array}$ & $(16,19)$ \\
\hline 5 & EGCG and hepatic stellate cells (HepG2) & $\begin{array}{l}\text { miR-221, miR-181a, and } \\
\text { miR-10b }\end{array}$ & OPN mRNA degradation and protective in liver injury & $(134)$ \\
\hline 6 & EGCG and Mouse lung adenocarcinoma & $\operatorname{miR}-449 c-5 p$ & Myb pathway regulation & $(22)$ \\
\hline 7 & EGCG and melanoma cells & miR-let-7b & Laminin receptor signaling & $(135)$ \\
\hline 8 & EGCG and osteosarcoma & $\mathrm{miR}-1$ & Cell growth & (34) \\
\hline 9 & $\begin{array}{l}\text { EGCG and tobacco carcinogen-induced lung } \\
\text { tumor in A7J mice }\end{array}$ & miR-210 and other miRNAs & $\begin{array}{l}\text { HIF-1 } 1 \alpha \text {, cell growth AKT, NF-кB, MAP kinase, and } \\
\text { cell cycle }\end{array}$ & $(11)$ \\
\hline 10 & EGCG and SH-SY5Y and SK-N-DZ & $\operatorname{miR}-7-1$ & Induction of apoptosis & $(10)$ \\
\hline 11 & Human lung cancer and EGCG or green tea & $\operatorname{miR}-7$ & Apoptosis induction and inhibition of proliferation & $(136)$ \\
\hline 12 & Polyphenon-60 and MCF-7 & miR-21 and miR-27 & $\begin{array}{l}\text { Downregulation of the tumor suppressor } \\
\text { gene-tropomyosin-1 }\end{array}$ & $(137)$ \\
\hline 13 & $\begin{array}{l}\text { EGCG and human hepatocellular carcinoma } \\
\text { HepG2 }\end{array}$ & $\operatorname{miR}-16$ & $\begin{array}{l}\text { Induction of apoptosis (by downregulating the } \\
\text { apoptotic protein BCL2) }\end{array}$ & (9) \\
\hline
\end{tabular}


release of intravesicular $\mathrm{Ca}^{2+}$ into the cytosol $(102,103)$. The calcium store exhaustion stimulates $\mathrm{Ca}^{2+}$ influx across the plasma membrane of the $\mathrm{T}$ cells, a process called store-operated $\mathrm{Ca}^{2+}$ entry (SOCE) (104-106). SOCE results from assembly of calcium release-activated calcium (CRAC) channel protein 1 , which is encoded by the Orail gene with the ER $\mathrm{Ca}^{2+}$ sensing proteins STIM1 and STIM2 (106). Orail-mediated $\mathrm{Ca}^{2+}$ influx in $\mathrm{T}$ cells depends on a negative membrane potential delivering the electrical driving force for $\mathrm{Ca}^{2+}$ entry into the cells $(100,106)$. The membrane is polarized by opening of $\mathrm{K}^{+}$ channels and depolarized by opening of $\mathrm{Na}^{+}$channels. Two $\mathrm{K}^{+}$channels are known to be activated upon $\mathrm{Ca}^{2+}$ influxthe voltage-gated $\mathrm{K}^{+}$channel $\left(\mathrm{K}_{\mathrm{V}} 1.3\right)$ and the calcium-activated $\mathrm{K}^{+}$channels ( $\left.\mathrm{K}_{\mathrm{Ca}} 3.1\right)$ (107-111). Negative feedback provided to these $\mathrm{K}^{+}$channels is established by the transient receptor potential cation channel, subfamily $\mathrm{M}$, member 4 (TRPM4), which mediates $\mathrm{Na}^{+}$entry, thus depolarizing the membrane and curtailing $\mathrm{Ca}^{2+}$ entry through Orail (112). Further, the cell membrane potential also affects $\mathrm{Cl}^{-}$flux through $\mathrm{Cl}^{-}$channels and thus cell volume. When cells are exposed to hypotonic conditions, this results in swelling of $\mathrm{T}$ cells and $\mathrm{Cl}^{-}$channels start to operate. Cell swelling triggers the efflux of $\mathrm{Cl}^{-}$and eventually water from the cells, which returns the cell to its normal volume (102). The movement of $\mathrm{Ca}^{2+}, \mathrm{K}^{+}, \mathrm{Na}^{+}$, and $\mathrm{Cl}^{-}$ions ultimately affects the release of $\mathrm{Ca}^{2+}$; thus, regulating the performance of these ion channels would help to shape the signaling in $\mathrm{T}$ cells pivotal in development of Th cells and function (102).

The significance of ion channel function in T cells is mostly derived from genetic studies performed in murine models using either ion channel-specific gene knockout or siRNA knockdown (103). STIM1/2 or Orail (CRAC) knockout murine models have improved our knowledge on how these proteins participate in defective $\mathrm{T}$ cells' development contemplating the functions of these proteins in $\mathrm{Ca}^{2+}$ signaling $(100,102,113)$. Furthermore, patients with mutations in these genes also have profound defects in $\mathrm{T}$ cell development and function and are therefore immunodeficient (104). In mice, depletion of these genes disrupts the production of IL-2, IFN- $\gamma$, IL-17 and TNF$\alpha$, and thereby inhibits development of all $\mathrm{Th}$ cell classes $(106,114)$. The knockout of $\mathrm{K}_{\mathrm{Ca}} 3.1$ or $\mathrm{K}_{\mathrm{V}} 1.3$ results in the reduction of $\mathrm{Ca}^{2+}$ influx upon stimulation of $\mathrm{T}$ cells (108, $109,111)$. Inflammatory cytokines, namely, IFN- $\gamma$ and IL-17, are attenuated, indicating a defect in the development and/or function of these inflammatory Th cell types (115). However, Treg development and function appear normal and these mice are resistant to autoimmune disorders (108). Deletion of $\mathrm{K}_{\mathrm{Ca}} 3.1$ protects mice from developing colitis whereas $\mathrm{K}_{\mathrm{V}} 1.3$ gene deletion prefers $\mathrm{T}$ cells toward immunoregulatory in function and renders the gene knockout mice impervious to autoimmune encephalomyelitis $(109,116,117)$. Therefore, $\mathrm{K}^{+}$channels are differentially required for the development and function of the various Th cell types. In addition, the $\mathrm{K}_{\mathrm{V}} 1.3$ channel is specifically upregulated in Th17 cells and is required for its activation and cytokine production (108). With regard to $\mathrm{Na}^{+}$channels, gene array analysis indicates that TRPM4 is expressed more in Th2 compared to Th1 cells (112). Experiments performed in
T cells for TRPM4 gene silencing using siRNA increases $\mathrm{Ca}^{2+}$ influx in Th2 cells, whereas it decreases $\mathrm{Ca}^{2+}$ influx in Th1 cells $(102,112)$. It also affects the $\mathrm{T}$ cell cytokine production of IL-2, IL-4 and IFN- $\gamma$ in addition to cell mobility. However, the mechanisms underlying those effects are incompletely understood because the expression of Th1 and Th2 transcription factors Tbet and GATA3 are not affected, respectively (112, 118). In summary, these studies suggest that ion channels are differentially involved for the development and function of Th cell subtypes.

So far, only few studies were performed to understand the influence of green tea on SOCE pathway in $\mathrm{CD}^{+}$ immune $\mathrm{T}$ cells $(5,48,92,94,119-121)$. Other immune cells such as mast cells were given the treatment of EGCG in varying doses, which could inhibit the functions of mast cells such as degranulation, leukotriene C4 secretion, and SOCE $\left(\mathrm{Ca}^{2+}\right.$ flow) through mitochondrial calcium dysfunctions (119). In human Jurkat $\mathrm{T}$ cells, it is demonstrated that EGCG is capable to diminish the calcium influx $(48,120)$. Recently, one study in murine primary $\mathrm{CD}^{+} \mathrm{T}$ cells

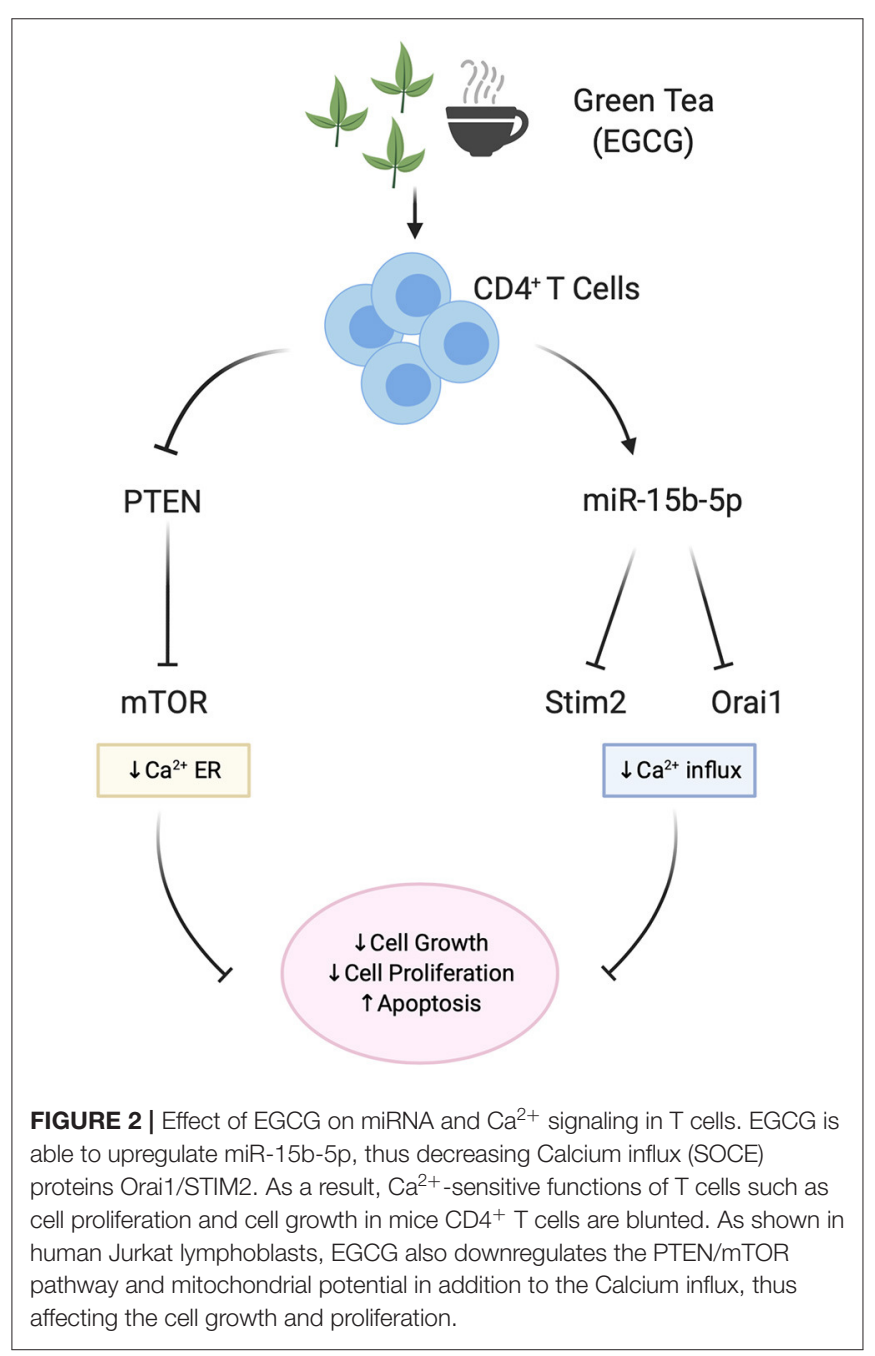


suggested that EGCG is able to inhibit the SOCE in a dosedependent fashion and affects cell proliferation and apoptosis (48). Thus, EGCG inhibits $\mathrm{Ca}^{2+}$ influx in immune cells including $\mathrm{T}$ cells.

\section{EGCG CONTROLS MIRNAS EXPRESSION IN CANCER AND IMMUNE T CELLS}

MicroRNAs (miRNAs) are non-coding very small (singlestranded $\sim 19-23$ nucleotides) RNA molecules that regulate at least one third of genome (gene expression) at the posttranscriptional level (122). These miRNAs are instructed by host genes and appear to present in both intronic and exonic regions of protein-coding genes as well as in noncoding genes (123-125). In general, the process of miRNAs biogenesis begins in the nucleus of a $\mathrm{T}$ cell or other cell types from a primary miRNA (pri-miR) transcript, which changes into a secondary structure comprising either one or more hairpin loops or lollipop structures (126-128). These hairpin loops or lollipop structures are identified and processed by the microprocessor complex enzymes constituted of DiGeorge syndrome critical region 8 (DGR8) and Drosha $(127,129,130)$. This enzymatic process yields a stem loop precursor miRNA (pre-miR) that consists of roughly 60-70 nucleotides. The pre$\mathrm{miR}$ is transported to the cytoplasm by another protein called exportin-5 where it undertakes a secondary processing stage by another RNase III enzyme called Dicer yielding a RNA duplex of 19-23 nucleotides (130). This double-stranded RNA duplex is amalgamated into the RNA-induced silencing complex (RISC), where one of the RNA strands results in degradation while the subsequent RNA strand forms the mature miRNA involved in a post-translational process (131). Overall, most of the mature miRNA attaches to the $3^{\prime}$ UTR untranslated region (UTR) of its target mRNA transcript. However, in some instances, mature miRNAs could also attach to the $5^{\prime}$ UTR and the protein coding region of the gene (128). Once the binding is completed, then RISC either inhibits the translational process or degrades the targeted mRNA, thus decreasing protein expression $(123,132)$. Dysregulated miRNAs are involved in several pathological conditions including autoimmunity, infection, and cancer (125).

Various studies suggested that EGCG is able to upregulate several different miRNAs and also downregulates several of them; however, most of the studies focused on the miRNAs that were upregulated after green tea and its components such as EGCG (Table 2), thus affecting gene regulation and the respective cell functions such as cell proliferation, apoptosis, etc.

The contribution of miRNAs in the modification of Th cell development and function by EGCG has recently been uncovered $(48,138)$. One study suggested that EGCG upregulates miR-15b with subsequent suppression of Orail/STIM2 protein synthesis and blunted SOCE (48). This study suggested that miR-15b could be a powerful post-transcriptional regulator of calcium entry and thus of calcium-sensitive functions of $\mathrm{T}$ cells (Figure 2).
EGCG differentially augments the expression of several miRNAs (Table 2) that are involved in the NF- $\kappa$ B inflammatory pathway (11), the retinoid $\mathrm{X}$ receptor $\alpha(\mathrm{RXR} \alpha)$ signaling pathway (15), downregulation of apoptotic protein (10) such as BCL2 (9), downregulation of tumor suppressor genes tropomyosin-1 (137), laminin receptor signaling (135), Myb pathway modulation (22), Cox2 signaling $(16,19)$, and calcium signaling (139). As scientific advances are developed in miRNA and tea research, an increasing number of molecular effects are recognized due to miRNA regulation. miRNAs induced by green tea have wide-ranging beneficial effects: tumor suppression by negatively regulating gene expression of oncogenic factors, reduction in hypertension and neurodegeneration, and improvement in arthritis $(10,16,19,34,133,137)$. Generally, green tea is safe to consume even at high concentrations. Thus, if the cytotoxic effects of green tea can be associated to a specific miRNA, it is plausible that treatments targeting the overexpressed miRNA could be harnessed for treatment of several pathologies. Prospective studies are needed to define which miRNAs could be exploited for therapeutic applications.

\section{CONCLUDING REMARKS AND SUMMARY}

In recent decades, there is a growing trend in the use of alternative therapies, and plant-based medicinal phytochemicals are among the most suited in inflammatory diseases. Therefore, an appropriate record of traditional herbal medicine in combination with modern scientific/pharmacological investigation is needed to corroborate or disprove the medicinal properties of these countless traditional Phytotherapies used in ancient times in many countries throughout the world (140). In this regard, EGCG from green tea is one of the substances with several historical beneficial effects on various disorders such as cancer, metabolic diseases, and inflammation (89). In $\mathrm{CD}^{+}{ }^{+} \mathrm{T}$ cells, it appears that EGCG is a powerful regulator of $\mathrm{Ca}^{2+}$ signaling by miRNA expression and, thus, by modification of gene expression at the post-transcriptional level. Therefore, it is worth exploring the potential mechanisms of polyphenols in the regulation of other biological processes in addition to immune response.

\section{AUTHOR CONTRIBUTIONS}

YS, MS, and FL have collected the literature and wrote the review. All authors contributed to the article and approved the submitted version.

\section{FUNDING}

MS received the Margarete von Wrangell (MvW 317635.41/118/3) habilitation scholarship co-funded by the Ministry of Science, Research and the Arts (MWK) of the state of Baden-Württemberg and by the European Social Funds. Figures are created by https://biorender.com/ online tool. The study has been supported by the Deutsche Forschungsgemeinschaft (DFG) and the Open Access Fund of the University of Tübingen, Germany. 


\section{REFERENCES}

1. Yang EJ, Lee J, Lee SY, Kim EK, Moon YM, Jung YO, et al. EGCG attenuates autoimmune arthritis by inhibition of STAT3 and HIF-1alpha with Th17/Treg control. PLoS ONE. (2014) 9:e86062. doi: 10.1371/journal.pone.0086062

2. Dragicevic N, Smith A, Lin X, Yuan F, Copes N, Delic V, et al. Green tea epigallocatechin-3-gallate (EGCG) and other flavonoids reduce alzheimer's amyloid-induced mitochondrial dysfunction. J Alzheimers Dis. (2011) 26:507-21. doi: 10.3233/JAD-2011-101629

3. Sharma R, Sharma A, Kumari A, Kulurkar PM, Raj R, Gulati A, et al. Consumption of green tea epigallocatechin-3-gallate enhances systemic immune response, antioxidative capacity and HPA axis functions in aged male swiss albino mice. Biogerontology. (2017) 18:367-82. doi: 10.1007/s10522-017-9696-6

4. Priya SR, Ashish K, Rajesh L, Parmod V. Tea: production, composition, consumption and its potential an antioxidant and antimicrobial agent. Intl J Food Ferment Technol. (2015) 5:95-106. doi: 10.5958/2277-9396.2016.00002.7

5. Wu D, Guo Z, Ren Z, Guo W, Meydani NS. Green tea EGCG suppresses $T$ cell proliferation through impairment of IL-2/IL-2 receptor signaling. Free Radic Biol Med. (2009) 47:636-43. doi: 10.1016/j.freeradbiomed.2009.06.001

6. Singh BN, Shankar S, Srivastava KR. Green tea catechin, epigallocatechin-3gallate (EGCG): mechanisms, perspectives and clinical applications. Biochem Pharmacol. (2011) 82:1807-21. doi: 10.1016/j.bcp.2011.07.093

7. Pae M, Wu D. Immunomodulating effects of epigallocatechin-3-gallate from green tea: mechanisms and applications. Food Funct. (2013) 4:1287303. doi: $10.1039 / \mathrm{c} 3$ fo60076a

8. Yu NH, Pei H, Huang YP, Li FY. (-)-Epigallocatechin-3-gallate inhibits arsenic-induced inflammation and apoptosis through suppression of oxidative stress in mice. Cell Physiol Biochem. (2017) 41:1788-800. doi: 10.1159/000471911

9. Tsang WP, Kwok TT. Epigallocatechin gallate up-regulation of miR-16 and induction of apoptosis in human cancer cells. J Nutr Biochem. (2010) 21:140-6. doi: 10.1016/j.jnutbio.2008.12.003

10. Chakrabarti M, Ai W, Banik NL, Ray KS. Overexpression of miR-7-1 increases efficacy of green tea polyphenols for induction of apoptosis in human malignant neuroblastoma SH-SY5Y and SK-N-DZ cells. Neurochem Res. (2013) 38:420-32. doi: 10.1007/s11064-012-0936-5

11. Zhou H, Chen JX, Yang CS, Yang MQ, Deng Y, Wang H. Gene regulation mediated by microRNAs in response to green tea polyphenol EGCG in mouse lung cancer. BMC Genomics. (2014) 15(Suppl. 11):S3. doi: 10.1186/1471-2164-15-S11-S3

12. Zeng L, Holly JM, Perks MC. Effects of physiological levels of the green tea extract epigallocatechin-3-gallate on breast cancer cells. Front Endocrinol. (2014) 5:61. doi: 10.3389/fendo.2014.00061

13. Liu S, Xu ZL, Sun L, Liu Y, Li CC, Li HM, et al. -(-)Epigallocatechin3gallate induces apoptosis in human pancreatic cancer cells via PTEN. Mol Med Rep. (2016) 14:599-605. doi: 10.3892/mmr.2016.5277

14. Sanna V, Singh CK, Jashari R, Adhami VM, Chamcheu JC, Rady I, et al. Targeted nanoparticles encapsulating (-)-epigallocatechin-3gallate for prostate cancer prevention and therapy. Sci Rep. (2017) 7:41573. doi: $10.1038 /$ srep 41573

15. Jiang P, Xu C, Chen L, Chen A, Wu X, Zhou M, et al. Epigallocatechin3-gallate inhibited cancer stem cell-like properties by targeting hamir-485-5p/RXRalpha in lung cancer. J Cell Biochem. (2018) 119:862335. doi: $10.1002 /$ jcb. 27117

16. Rasheed Z, Rasheed N, Al-Shobaili AH. Epigallocatechin-3-O-gallate upregulates microRNA-199a-3p expression by down-regulating the expression of cyclooxygenase- 2 in stimulated human osteoarthritis chondrocytes. J Cell Mol Med. (2016) 20:2241-8. doi: 10.1111/jcmm.12897

17. Westphal S, McGeary A, Rudloff S, Wilke A, Penack O. The green tea catechin epigallocatechin gallate ameliorates graft-versus-host disease. PLoS ONE. (2017) 12:e0169630. doi: 10.1371/journal.pone. 0169630

18. Zhou T, Zhu M, Liang Z. (-)-Epigallocatechin-3-gallate modulates peripheral immunity in the MPTP-induced mouse model of parkinson's disease. Mol Med Rep. (2018) 17:4883-8. doi: 10.3892/mmr.2018.8470
19. Rasheed Z, Rasheed N, Al-Shaya O. Epigallocatechin-3-O-gallate modulates global microRNA expression in interleukin-1beta-stimulated human osteoarthritis chondrocytes: potential role of EGCG on negative coregulation of microRNA-140-3p and ADAMTS5. Eur J Nutr. (2018) 57:917-28. doi: 10.1007/s00394-016-1375-x

20. Singh NA, Mandal AK, Khan AZ. Potential neuroprotective properties of epigallocatechin-3-gallate (EGCG). Nutr J. (2016) 15:60. doi: 10.1186/s12937-016-0179-4

21. Wong CP, Nguyen LP, Noh SK, Bray TM, Bruno RS, Ho E. Induction of regulatory T cells by green tea polyphenol EGCG. Immunol Lett. (2011) 139:7-13. doi: 10.1016/j.imlet.2011.04.009

22. Zhou H, Manthey J, Lioutikova E, Yang W, Yoshigoe K, Yang MQ, et al. The up-regulation of Myb may help mediate EGCG inhibition effect on mouse lung adenocarcinoma. Hum Genomics. (2016) 10(Suppl. 2):19. doi: 10.1186/s40246-016-0072-4

23. Khan $\mathrm{N}$, Mukhtar $\mathrm{H}$. Cancer and metastasis: prevention and treatment by green tea. Cancer Metastasis Rev. (2010) 29:435-45. doi: 10.1007/s10555-010-9236-1

24. Yang CS, Chen L, Lee MJ, Balentine D, Kuo MC, Schantz SP. Blood and urine levels of tea catechins after ingestion of different amount of green tea by human volunteers. Cancer Epidemiol. Bimark. Prev. (1998) 7:351-4.

25. Zhou J, Farah BL, Sinha RA, Wu Y, Singh BK, Bay BH, et al. Epigallocatechin-3-gallate (EGCG), a green tea polyphenol, stimulates hepatic autophagy and lipid clearance. PLOS ONE. (2014) 9:e87161. doi: 10.1371/journal.pone.0087161

26. Howells LM, Moiseeva EP, Neal CP, Foreman BE, Andreadi CK, Sun YY, et al. Predicting the physiological relevance of in vitro cancer preventive activities of phytochemicals. Acta Pharmacol Sin. (2007) 28:1274304. doi: 10.1111/j.1745-7254.2007.00690.x

27. Peter B, Bosze S, Horvath R. Biophysical characteristics of proteins and living cells exposed to the green tea polyphenol epigallocatechin-3-gallate (EGCg): review of recent advances from molecular mechanisms to nanomedicine and clinical trials. Eur Biophys J. (2017) 46:1-24. doi: 10.1007/s00249-016-1141-2

28. Rein MJ, Renouf M, Cruz-Hernandez C, Actis-Goretta L, Thakkar SK, da Silva Pinto M. Bioavailability of bioactive food compounds: a challenging journey to bioefficacy. Br J Clin Pharmacol. (2013) 75:588602. doi: 10.1111/j.1365-2125.2012.04425.x

29. Cai ZY, Li XM, Liang JP, Xiang LP, Wang KR, Shi YL, et al. Bioavailability of tea catechins and its improvement. Molecules. (2018) 23:2346. doi: 10.3390/molecules 23092346

30. Wang CC, Xu H, Man GC, Zhang T, Chu KO, Chu CY, et al. Prodrug of green tea epigallocatechin-3-gallate (Pro-EGCG) as a potent antiangiogenesis agent for endometriosis in mice. Angiogenesis. (2013) 16:5969. doi: 10.1007/s10456-012-9299-4

31. Stenvang M, Dueholm MS, Vad BS, Seviour T, Zeng G, Geifman-Shochat S, et al. Epigallocatechin gallate remodels overexpressed functional amyloids in pseudomonas aeruginosa and increases biofilm susceptibility to antibiotic treatment. J Biol Chem. (2016) 291:26540-53. doi: 10.1074/jbc.M116.739953

32. Wang H, Bian S, Yang SC. Green tea polyphenol EGCG suppresses lung cancer cell growth through upregulating miR-210 expression caused by stabilizing HIF-1alpha. Carcinogenesis. (2011) 32:1881-9. doi: 10.1093/carcin/bgr218

33. Ranzato E, Magnelli V, Martinotti S, Waheed Z, Cain SM, Snutch TP, et al. Epigallocatechin-3-gallate elicits Ca2+ spike in MCF-7 breast cancer cells: essential role of Cav3.2 channels. Cell Calcium. (2014) 56:28595. doi: $10.1016 /$ j.ceca.2014.09.002

34. Zhu K, Wang W. Green tea polyphenol EGCG suppresses osteosarcoma cell growth through upregulating miR-1. Tumour Biol. (2016) 37:437382. doi: 10.1007/s13277-015-4187-3

35. Peairs A, Dai R, Gan L, Shimp S, Rylander MN, Li L, et al. Epigallocatechin-3gallate (EGCG) attenuates inflammation in MRL/lpr mouse mesangial cells. Cell Mol Immunol. (2010) 7:123-32. doi: 10.1038/cmi.2010.1

36. Pae M, Ren Z, Meydani M, Shang F, Smith D, Meydani SN, et al. Dietary supplementation with high dose of epigallocatechin-3-gallate promotes inflammatory response in mice. J Nutr Biochem. (2012) 23:52631. doi: 10.1016/j.jnutbio.2011.02.006

37. Byun JK, Yoon BY, Jhun JY, Oh HJ, Kim EK, Min JK, et al. Epigallocatechin3 -gallate ameliorates both obesity and autoinflammatory arthritis aggravated 
by obesity by altering the balance among $\mathrm{CD} 4+\mathrm{T}$-cell subsets. Immunol Lett. (2014) 157:51-9. doi: 10.1016/j.imlet.2013.11.006

38. Peter B, Farkas E, Forgacs E, Saftics A, Kovacs B, Kurunczi S, et al. Green tea polyphenol tailors cell adhesivity of RGD displaying surfaces: multicomponent models monitored optically. Sci Rep. (2017) 7:42220. doi: $10.1038 /$ srep 42220

39. Oz HS. Chronic inflammatory diseases and green tea polyphenols. Nutrients. (2017) 9:561. doi: 10.3390/nu9060561

40. Hu R, He Z, Liu M, Tan J, Zhang H, Hou DX, et al. Dietary protocatechuic acid ameliorates inflammation and up-regulates intestinal tight junction proteins by modulating gut microbiota in LPS-challenged piglets. J Anim Sci Biotechnol. (2020) 11:92. doi: 10.1186/s40104-020-00492-9

41. Jung ES, Park JI, Park H, Holzapfel W, Hwang JS, Lee HC. Sevenday green tea supplementation revamps gut microbiome and caecum/skin metabolome in mice from stress. Sci Rep. (2019) 9:18418. doi: 10.1038/s41598-019-54808-5

42. Jin JS, Touyama M, Hisada T, Benno Y. Effects of green tea consumption on human fecal microbiota with special reference to bifidobacterium species. Microbiol Immunol. (2012) 56:729-39. doi: 10.1111/j.1348-0421.2012.00502.x

43. Yuan X, Long Y, Ji Z, Gao J, Fu T, Yan M, et al. Green tea liquid consumption alters the human intestinal and oral microbiome. Mol Nutr Food Res. (2018) 62:e1800178. doi: $10.1002 / \mathrm{mnfr} .201800178$

44. Adami GR, Tangney CC, Tang JL, Zhou Y, Ghaffari S, Naqib A, et al. Effects of green tea on miRNA and microbiome of oral epithelium. Sci Rep. (2018) 8:5873. doi: 10.1038/s41598-018-22994-3

45. Jung ES, Park HM, Hyun SM, Shon JC, Singh D, Liu KH, et al. The green tea modulates large intestinal microbiome and exo/endogenous metabolome altered through chronic UVB-exposure. PLoS ONE. (2017) 12:e0187154. doi: 10.1371/journal.pone.0187154

46. Hodgson AB, Randell RK, Mahabir-Jagessar TK, Lotito S, Mulder T, Mela DJ, et al. Acute effects of green tea extract intake on exogenous and endogenous metabolites in human plasma. J Agric Food Chem. (2014) 62:1198-208. doi: 10.1021/j4404872y

47. Liu Z, de Bruijn WJC, Bruins ME, Vincken PJ. Reciprocal interactions between epigallocatechin-3-gallate (EGCG) and human gut microbiota in vitro. J Agric Food Chem. (2020) 68:9804-15. doi: 10.1021/acs.jafc.0c03587

48. Zhang S, Al-Maghout T, Bissinger R, Zeng N, Pelzl L, Salker MS, et al. Epigallocatechin-3-gallate (EGCG) up-regulates miR-15b expression thus attenuating store operated calcium entry (SOCE) into murine CD4+ T cells and human leukaemic T cell lymphoblasts. Oncotarget. (2017) 8:8950014. doi: 10.18632/oncotarget.20032

49. Wang J, Pae M, Meydani SN, Wu D. Green tea epigallocatechin-3-gallate modulates differentiation of naive $\mathrm{CD} 4(+) \mathrm{T}$ cells into specific lineage effector cells. J Mol Med. (2013) 91:485-95. doi: 10.1007/s00109-012-0964-2

50. Fontenot JD, Gavin MA, Rudensky YA. Foxp3 programs the development and function of CD4+CD25+ regulatory T cells. Nat Immunol. (2003) 4:330-6. doi: 10.1038/ni904

51. Zhou X, Bailey-Bucktrout S, Jeker LT, Bluestone AJ. Plasticity of $\mathrm{CD} 4(+)$ FoxP3(+) T cells. Curr Opin Immunol. (2009) 21:281-5. doi: 10.1016/j.coi.2009.05.007

52. Zhu J, Paul EW. Heterogeneity and plasticity of T helper cells. Cell Res. (2010) 20:4-12. doi: 10.1038/cr.2009.138

53. Sakaguchi S, Vignali DA, Rudensky AY, Niec RE, Waldmann H. The plasticity and stability of regulatory T cells. Nat Rev Immunol. (2013) 13:4617. doi: $10.1038 /$ nri3464

54. Elyaman W, Khoury JS. Th9 cells in the pathogenesis of EAE and multiple sclerosis. Semin Immunopathol. (2017) 39:79-87. doi: 10.1007/s00281-016-0604-y

55. Bluestone JA, Mackay CR, O'Shea JJ, Stockinger B. The functional plasticity of T cell subsets. Nat Rev Immunol. (2009) 9:811-6. doi: 10.1038/nri2654

56. Korn T, Bettelli E, Oukka M, Kuchroo KV. IL-17 and Th17 cells. Annu Rev Immunol. (2009) 27:485517. doi: 10.1146/annurev.immunol.021908.132710

57. Soroosh P, Doherty AT. Th9 and allergic disease. Immunology. (2009) 127:450-8. doi: 10.1111/j.1365-2567.2009.03114.x
58. Zhou L, Chong MM, Littman RD. Plasticity of CD4+ $\mathrm{T}$ cell lineage differentiation. Immunity. (2009) 30:64655. doi: 10.1016/j.immuni.2009.05.001

59. Hori S. Developmental plasticity of Foxp3+ regulatory T cells. Curr Opin Immunol. (2010) 22:575-82. doi: 10.1016/j.coi.2010.08.004

60. Perumal NB, Kaplan HM. Regulating Il9 transcription in T helper cells. Trends Immunol. (2011) 32:146-50. doi: 10.1016/j.it.2011.01.006

61. Wilhelm C, Hirota K, Stieglitz B, Van Snick J, Tolaini M, Lahl K, et al. An IL-9 fate reporter demonstrates the induction of an innate IL-9 response in lung inflammation. Nat Immunol. (2011) 12:1071-7. doi: 10.1038/ni.2133

62. Schmitt E, Bopp T. Amazing IL-9: revealing a new function for an "old" cytokine. J Clin Invest. (2012) 122:3857-9. doi: 10.1172/JCI65929

63. Jabeen R, Kaplan HM. The symphony of the ninth: the development and function of Th9 cells. Curr Opin Immunol. (2012) 24:303-7. doi: 10.1016/j.coi.2012.02.001

64. Bettelli E, Carrier Y, Gao W, Korn T, Strom TB, Oukka M, et al. Reciprocal developmental pathways for the generation of pathogenic effector TH17 and regulatory T cells. Nature. (2006) 441:235-8. doi: 10.1038/nature04753

65. Schulte S, Sukhova GK, Libby P. Genetically programmed biases in Th1 and Th2 immune responses modulate atherogenesis. Am J Pathol. (2008) 172:1500-8. doi: 10.2353/ajpath.2008.070776

66. O'Shea JJ, Steward-Tharp SM, Laurence A, Watford WT, Wei L, Adamson AS, et al. Signal transduction and Th17 cell differentiation. Microbes Infect. (2009) 11:599-611. doi: 10.1016/j.micinf.2009.04.007

67. Veldhoen M, Uyttenhove C, van Snick J, Helmby H, Westendorf A, Buer J, et al. Transforming growth factor-beta 'reprograms' the differentiation of $\mathrm{T}$ helper 2 cells and promotes an interleukin 9-producing subset. Nat Immunol. (2008) 9:1341-6. doi: 10.1038/ni.1659

68. Dardalhon V, Awasthi A, Kwon H, Galileos G, Gao W, Sobel RA, et al. IL-4 inhibits TGF-beta-induced Foxp3+ T cells and, together with TGFbeta, generates IL-9+ IL-10+ Foxp3(-) effector T cells. Nat Immunol. (2008) 9:1347-55. doi: 10.1038/ni.1677

69. Jager A, Dardalhon V, Sobel RA, Bettelli E, Kuchroo KV. Th1, Th17, and Th9 effector cells induce experimental autoimmune encephalomyelitis with different pathological phenotypes. J Immunol. (2009) 183:716977. doi: 10.4049/jimmunol.0901906

70. Tofukuji S, Kuwahara M, Suzuki J, Ohara O, Nakayama T, Yamashita M. Identification of a new pathway for Th1 cell development induced by cooperative stimulation with IL-4 and TGF-beta. J Immunol. (2012) 188:4846-57. doi: 10.4049/jimmunol.1103799

71. Eyerich S, Eyerich K, Pennino D, Carbone T, Nasorri F, Pallotta S, et al. Th22 cells represent a distinct human $\mathrm{T}$ cell subset involved in epidermal immunity and remodeling. J Clin Invest. (2009) 119:357385. doi: $10.1172 /$ JCI40202

72. Leung JM, Davenport M, Wolff MJ, Wiens KE, Abidi WM, Poles MA, et al. IL-22-producing CD4+ cells are depleted in actively inflamed colitis tissue. Mucosal Immunol. (2014) 7:124-33. doi: 10.1038/mi.2013.31

73. Lu P, Abedi V, Mei Y, Hontecillas R, Hoops S, Carbo A, et al. Supervised learning methods in modeling of $\mathrm{CD} 4+\mathrm{T}$ cell heterogeneity. BioData Min. (2015) 8:27. doi: 10.1186/s13040-015-0060-6

74. Kemeny DM. The role of the $\mathrm{T}$ follicular helper cells in allergic disease. Cell Mol Immunol. (2012) 9:386-9. doi: 10.1038/cmi.2012.31

75. Vinuesa CG, Fagarasan S, Dong C. New territory for T follicular helper cells. Immunity. (2013) 39:417-20. doi: 10.1016/j.immuni.2013.09.001

76. Hale JS, Ahmed R. Memory T follicular helper CD4 T cells. Front Immunol. (2015) 6:16. doi: 10.3389/fimmu.2015.00016

77. Maul J, Baumjohann D. Emerging roles for MicroRNAs in $T$ follicular helper cell differentiation. Trends Immunol. (2016) 37:297-309. doi: 10.1016/j.it.2016.03.003

78. Sugimoto N, Oida T, Hirota K, Nakamura K, Nomura T, Uchiyama T, et al. Foxp3-dependent and -independent molecules specific for CD25+CD4+ natural regulatory $\mathrm{T}$ cells revealed by DNA microarray analysis. Int Immunol. (2006) 18:1197-209. doi: 10.1093/intimm/dxl060

79. Fantini MC, Dominitzki S, Rizzo A, Neurath MF, Becker C. In vitro generation of CD4+ CD25+ regulatory cells from murine naive T cells. Nat Protoc. (2007) 2:1789-94. doi: 10.1038/nprot.2007.258 
80. Rubtsov YP, Niec RE, Josefowicz S, Li L, Darce J, Mathis D, et al. Stability of the regulatory T cell lineage in vivo. Science. (2010) 329:166771. doi: 10.1126/science.1191996

81. Brusko TM, Koya RC, Zhu S, Lee MR, Putnam AL, McClymont SA, et al. Human antigen-specific regulatory $\mathrm{T}$ cells generated by $\mathrm{T}$ cell receptor gene transfer. PLoS ONE. (2010) 5:e11726. doi: 10.1371/journal.pone.0011726

82. Tousif S, Singh Y, Prasad DV, Sharma P, Van Kaer L, Das G. T cells from programmed death-1 deficient mice respond poorly to mycobacterium tuberculosis infection. PLoS ONE. (2011) 6:e19864. doi: 10.1371/journal.pone.0019864

83. Singer BD, King LS, D’Alessio RF. Regulatory T cells as immunotherapy. Front Immunol. (2014) 5:46. doi: 10.3389/fimmu.2014.00046

84. Haque M, Song J, Fino K, Sandhu P, Song X, Lei F, et al. Stem cellderived tissue-associated regulatory $\mathrm{T}$ cells ameliorate the development of autoimmunity. Sci Rep. (2016) 6:20588. doi: 10.1038/srep20588

85. Takeuchi $\mathrm{Y}$, Nishikawa $\mathrm{H}$. Roles of regulatory T cells in cancer immunity. Int Immunol. (2016) 28:401-9. doi: 10.1093/intimm/dxw025

86. Wang J, Ren Z, Xu Y, Xiao S, Meydani SN, Wu D. Epigallocatechin-3gallate ameliorates experimental autoimmune encephalomyelitis by altering balance among CD4+ T-cell subsets. Am J Pathol. (2012) 180:22134. doi: 10.1016/j.ajpath.2011.09.007

87. Cornwall S, Cull G, Joske D, Ghassemifar R. Green tea polyphenol "epigallocatechin-3-gallate", differentially induces apoptosis in CLL B-and Tcells but not in healthy B-and T-cells in a dose dependant manner. Leuk Res. (2016) 51:56-61. doi: 10.1016/j.leukres.2016.10.011

88. Kim YH, Won YS, Yang X, Kumazoe M, Yamashita S, Hara A, et al. Green tea catechin metabolites exert immunoregulatory effects on CD4(+) T cell and natural killer cell activities. J Agric Food Chem. (2016) 64:35917. doi: 10.1021/acs.jafc.6b01115

89. Lee SY, Jung YO, Ryu JG, Oh HJ, Son HJ, Lee SH, et al. Epigallocatechin-3-gallate ameliorates autoimmune arthritis by reciprocal regulation of $\mathrm{T}$ helper-17 regulatory $\mathrm{T}$ cells and inhibition of osteoclastogenesis by inhibiting STAT3 signaling. J Leukoc Biol. (2016) 100:559-68. doi: 10.1189/jlb.3A0514-261RR

90. Min SY, Yan M, Kim SB, Ravikumar S, Kwon SR, Vanarsa K, et al. Green tea epigallocatechin-3-gallate suppresses autoimmune arthritis through indoleamine-2,3-dioxygenase expressing dendritic cells and the nuclear factor, erythroid 2-like 2 antioxidant pathway. J Inflamm. (2015) 12:53. doi: 10.1186/s12950-015-0097-9

91. Ning W, Wang S, Dong X, Liu D, Fu L, Jin R, et al. Epigallocatechin-3-gallate (EGCG) suppresses the trafficking of lymphocytes to epidermal melanocytes via inhibition of JAK2: its implication for vitiligo treatment. Biol Pharm Bull. (2015) 38:1700-6. doi: 10.1248/bpb.b15-00331

92. Shin HY, Kim SH, Jeong HJ, Kim SY, Shin TY, Um JY, et al. Epigallocatechin3-gallate inhibits secretion of TNF-alpha, IL-6 and IL-8 through the attenuation of ERK and NF-kappaB in HMC-1 cells. Int Arch Allergy Immunol. (2007) 142:335-44. doi: 10.1159/000097503

93. D’Arena G, Simeon V, De Martino L, Statuto T, D’Auria F, Volpe $\mathrm{S}$, et al. Regulatory T-cell modulation by green tea in chronic lyphocytic leukemia. Int J Immunopathol Pharmacol. (2013) 26:117-25. doi: 10.1177/039463201302600111

94. Pae M, Ren Z, Meydani M, Shang F, Meydani SN, Wu D. Epigallocatechin3-gallate directly suppresses $\mathrm{T}$ cell proliferation through impaired IL2 utilization and cell cycle progression. J Nutr. (2010) 140:150915. doi: 10.3945/jn.110.124743

95. Shim JH, Choi HS, Pugliese A, Lee SY, Chae JI, Choi BY, et al. (-)Epigallocatechin gallate regulates CD3-mediated $\mathrm{T}$ cell receptor signaling in leukemia through the inhibition of ZAP-70 kinase. J Biol Chem. (2008) 283:28370-9. doi: 10.1074/jbc.M802200200

96. Williamson MP, McCormick TG, Nance CL, Shearer TW. Epigallocatechin gallate, the main polyphenol in green tea, binds to the T-cell receptor, CD4: potential for HIV-1 therapy. J Allergy Clin Immunol. (2006) 118:136974. doi: 10.1016/j.jaci.2006.08.016

97. Aktas O, Prozorovski T, Smorodchenko A, Savaskan NE, Lauster R, Kloetzel $\mathrm{PM}$, et al. Green tea epigallocatechin-3-gallate mediates T cellular NF- $\kappa \mathrm{B}$ inhibition and exerts neuroprotection in autoimmune encephalomyelitis. $J$ Immunol. (2004) 173:5794-800. doi: 10.4049/jimmunol.173.9.5794
98. Li HC, Yashiki S, Sonoda J, Lou H, Ghosh SK, Byrnes JJ, et al. Green tea polyphenols induce apoptosis in vitro in peripheral blood $\mathrm{T}$ lymphocytes of adult T-cell leukemia patients. Jpn J Cancer Res. (2000) 91:34-40. doi: 10.1111/j.1349-7006.2000.tb00857.x

99. Ehling $\mathrm{P}$, Bittner S, Budde $\mathrm{T}$, Wiendl $\mathrm{H}$, Meuth GS. Ion channels in autoimmune neurodegeneration. FEBS Lett. (2011) 585:3836-42. doi: 10.1016/j.febslet.2011.03.065

100. Shaw PJ, Feske S. Regulation of lymphocyte function by ORAI and STIM proteins in infection and autoimmunity. J Physiol. (2012) 590:415767. doi: 10.1113/jphysiol.2012.233221

101. Oh-hora M, Rao A. Calcium signaling in lymphocytes. Curr Opin Immunol. (2008) 20:250-8. doi: 10.1016/j.coi.2008.04.004

102. Feske S, Skolnik EY, Prakriya M. Ion channels and transporters in lymphocyte function and immunity. Nat Rev Immunol. (2012) 12:53247. doi: $10.1038 /$ nri3233

103. Fanger CM, Neben AL, Cahalan DM. Differential Ca2+ influx, KCa channel activity, and $\mathrm{Ca} 2+$ clearance distinguish Th1 and Th2 lymphocytes. $J$ Immunol. (2000) 164:1153-60. doi: 10.4049/jimmunol.164.3.1153

104. Feske S, Prakriya M, Rao A, Lewis SR. A severe defect in CRAC $\mathrm{Ca} 2+$ channel activation and altered $\mathrm{K}+$ channel gating in $\mathrm{T}$ cells from immunodeficient patients. J Exp Med. (2005) 202:651-62. doi: 10.1084/jem.20050687

105. Feske S, Gwack Y, Prakriya M, Srikanth S, Puppel SH, Tanasa B, et al. A mutation in Orail causes immune deficiency by abrogating CRAC channel function. Nature. (2006) 441:179-85. doi: 10.1038/nature04702

106. Oh-Hora M, Yamashita M, Hogan PG, Sharma S, Lamperti E, Chung W, et al. Dual functions for the endoplasmic reticulum calcium sensors STIM1 and STIM2 in T cell activation and tolerance. Nat Immunol. (2008) 9:43243. doi: $10.1038 /$ ni1574

107. Reneer MC, Estes DJ, Velez-Ortega AC, Norris A, Mayer M, Marti F. Peripherally induced human regulatory $\mathrm{T}$ cells uncouple Kv1.3 activation from TCR-associated signaling. Eur J Immunol. (2011) 41:31705. doi: 10.1002/eji.201141492

108. Gocke AR, Lebson LA, Grishkan IV, Hu L, Nguyen HM, Whartenby KA, et al. Kv1.3 deletion biases $\mathrm{T}$ cells toward an immunoregulatory phenotype and renders mice resistant to autoimmune encephalomyelitis. J Immunol. (2012) 188:5877-86. doi: 10.4049/jimmunol.1103095

109. Chimote AA, Hajdu P, Kucher V, Boiko N, Kuras Z, Szilagyi O, et al. Selective inhibition of $\mathrm{KCa} 3.1$ channels mediates adenosine regulation of the motility of human T cells. J Immunol. (2013) 191:627380. doi: 10.4049/jimmunol.1300702

110. Hou P, Zhang R, Liu Y, Feng J, Wang W, Wu Y, et al. Physiological role of Kv1.3 channel in T lymphocyte cell investigated quantitatively by kinetic modeling. PLoS ONE. (2014) 9:e89975. doi: 10.1371/journal.pone.0089975

111. Orban C, Bajnok A, Vasarhelyi B, Tulassay T, Toldi G. Different calcium influx characteristics upon Kv1.3 and IKCal potassium channel inhibition in T helper subsets. Cytometry A. (2014) 85:636-41. doi: 10.1002/cyto.a.22479

112. Weber KS, Hildner K, Murphy KM, Allen MP. Trpm4 differentially regulates Th1 and Th2 function by altering calcium signaling and NFAT localization. $J$ Immunol. (2010) 185:2836-46. doi: 10.4049/jimmunol.1000880

113. Greenberg ML, Yu Y, Leverrier S, Zhang SL, Parker I, Cahalan DM. Orai1 function is essential for T cell homing to lymph nodes. J Immunol. (2013) 190:3197-206. doi: 10.4049/jimmunol.1202212

114. Ma J, McCarl CA, Khalil S, Luthy K, Feske S. T-cell-specific deletion of STIM1 and STIM2 protects mice from EAE by impairing the effector functions of Th1 and Th17 cells. Eur J Immunol. (2010) 40:302842. doi: 10.1002/eji.201040614

115. Varga Z, Hajdu P, Panyi G. Ion channels in T lymphocytes: an update on facts, mechanisms and therapeutic targeting in autoimmune diseases. Immunol Lett. (2010) 130:19-25. doi: 10.1016/j.imlet.2009.12.015

116. Di L, Srivastava S, Zhdanova O, Ding Y, Li Z, Wulff H, et al. Inhibition of the K+ channel KCa3.1 ameliorates T cell-mediated colitis. Proc Natl Acad Sci USA. (2010) 107:1541-6. doi: 10.1073/pnas.0910133107

117. Di L, Srivastava S, Zhdanova O, Sun Y, Li Z, Skolnik YE. Nucleoside diphosphate kinase B knock-out mice have impaired activation of the $\mathrm{K}+$ channel KCa3.1, resulting in defective T cell activation. J Biol Chem. (2010) 285:38765-71. doi: 10.1074/jbc.M110.168070 
118. Weber KS, Miller MJ, Allen MP. Th17 cells exhibit a distinct calcium profile from Th1 and Th2 cells and have Th1-like motility and NF-AT nuclear localization. J Immunol. (2008) 180:1442-50. doi: 10.4049/jimmunol.180.3.1442

119. Inoue $\mathrm{T}$, Suzuki Y, Ra C. Epigallocatechin-3-gallate inhibits mast cell degranulation, leukotriene $\mathrm{C} 4$ secretion, and calcium influx via mitochondrial calcium dysfunction. Free Radic Biol Med. (2010) 49:632-40. doi: 10.1016/j.freeradbiomed.2010.05.015

120. Tofolean IT, Ganea C, Ionescu D, Filippi A, Garaiman A, Goicea A, et al. Cellular determinants involving mitochondrial dysfunction, oxidative stress and apoptosis correlate with the synergic cytotoxicity of epigallocatechin3-gallate and menadione in human leukemia Jurkat T cells. Pharmacol Res. (2016) 103:300-17. doi: 10.1016/j.phrs.2015.12.013

121. Soler F, Asensio MC, Fernandez-Belda F. Inhibition of the intracellular $\mathrm{Ca}(2+)$ transporter SERCA (sarco-endoplasmic reticulum $\mathrm{Ca}(2+)$-ATPase) by the natural polyphenol epigallocatechin-3-gallate. J Bioenerg Biomembr. (2012) 44:597-605. doi: 10.1007/s10863-012-9462-z

122. Lindsay MA. microRNAs and the immune response. Trends Immunol. (2008) 29:343-51. doi: 10.1016/j.it.2008.04.004

123. Bartel DP. MicroRNAs: target recognition and regulatory functions. Cell. (2009) 136:215-33. doi: 10.1016/j.cell.2009.01.002

124. Kluiver J, Gibcus JH, Hettinga C, Adema A, Richter MK, Halsema N, et al. Rapid generation of microRNA sponges for microRNA inhibition. PLoS ONE. (2012) 7:e29275. doi: 10.1371/journal.pone.0029275

125. Kroesen BJ, Teteloshvili N, Smigielska-Czepiel K, Brouwer E, Boots AM, van den Berg A, et al. Immuno-miRs: critical regulators of T-cell development, function and ageing. Immunology. (2015) 144:1-10. doi: 10.1111/ imm. 12367

126. Lund E, Guttinger S, Calado A, Dahlberg JE, Kutay U. Nuclear export of microRNA precursors. Science. (2004) 303:95-8. doi: 10.1126/science.1090599

127. Carthew RW, Sontheimer JE. Origins and mechanisms of miRNAs and siRNAs. Cell. (2009) 136:642-55. doi: 10.1016/j.cell.2009.01.035

128. Bronevetsky Y, Ansel MK. Regulation of miRNA biogenesis and turnover in the immune system. Immunol Rev. (2013) 253:304-16. doi: 10.1111/imr.12059

129. Kirigin FF, Lindstedt K, Sellars M, Ciofani M, Low SL, Jones L, et al. Dynamic microRNA gene transcription and processing during $\mathrm{T}$ cell development. J Immunol. (2012) 188:3257-67. doi: 10.4049/jimmunol. 1103175

130. Chong MM, Rasmussen JP, Rudensky AY, Littman RD. The RNAseIII enzyme Drosha is critical in $\mathrm{T}$ cells for preventing lethal inflammatory disease. J Exp Med. (2008) 205:2005-17. doi: 10.1084/jem.200 81219
131. Lin SL, Chang D, Ying YS. Asymmetry of intronic premiRNA structures in functional RISC assembly. Gene. (2005) 356:32-8. doi: 10.1016/j.gene.2005.04.036

132. Baek D, Villen J, Shin C, Camargo FD, Gygi SP, Bartel PD. The impact of microRNAs on protein output. Nature. (2008) 455:6471. doi: $10.1038 /$ nature 07242

133. Qian BJ, Tian CC, Ling XH, Yu LL, Ding FY, Huo JH, et al. miRNA-150-5p associate with antihypertensive effect of epigallocatechin-3-gallate revealed by aorta miRNome analysis of spontaneously hypertensive rat. Life Sci. (2018) 203:193-202. doi: 10.1016/j.lfs.2018.04.041

134. Arffa ML, Zapf MA, Kothari AN, Chang V, Gupta GN, Ding $\mathrm{X}$, et al. Epigallocatechin-3-gallate upregulates miR-221 to inhibit osteopontin-dependent hepatic fibrosis. PLoS ONE. (2016) 11:e0167435. doi: 10.1371/journal.pone.0167435

135. Yamada S, Tsukamoto S, Huang Y, Makio A, Kumazoe M, Yamashita S, et al. Epigallocatechin-3-O-gallate up-regulates microRNA-let-7b expression by activating $67-\mathrm{kDa}$ laminin receptor signaling in melanoma cells. Sci Rep. (2016) 6:19225. doi: 10.1038/srep19225

136. Zhong Z, Dong Z, Yang L, Chen X, Gong Z. Inhibition of proliferation of human lung cancer cells by green tea catechins is mediated by upregulation of let-7. Exp Ther Med. (2012) 4:267-72. doi: 10.3892/etm.2012.580

137. Fix LN, Shah M, Efferth T, Farwell MA, Zhang B. MicroRNA expression profile of MCF-7 human breast cancer cells and the effect of green tea polyphenon-60. Cancer Genomics Proteomics. (2010) 7:261-77.

138. Zhang S, Al-Maghout T, Zhou Y, Bissinger R, Abousaab A, Salker MS, et al. Role of dicer enzyme in the regulation of store operated calcium entry (SOCE) in CD4+ T cells. Cell Physiol Biochem. (2016) 39:13608. doi: $10.1159 / 000447840$

139. Cui C, Merritt R, Fu L, Pan Z. Targeting calcium signaling in cancer therapy. Acta Pharm Sin B. (2017) 7:3-17. doi: 10.1016/j.apsb.2016.11.001

140. Yuan $\mathrm{H}, \mathrm{Ma}$ Q, Ye L, Piao G. The traditional medicine and modern medicine from natural products. Molecules. (2016) 21:559. doi: 10.3390/molecules21050559

Conflict of Interest: The authors declare that the research was conducted in the absence of any commercial or financial relationships that could be construed as a potential conflict of interest.

Copyright $(\odot 2021$ Singh, Salker and Lang. This is an open-access article distributed under the terms of the Creative Commons Attribution License (CC BY). The use, distribution or reproduction in other forums is permitted, provided the original author(s) and the copyright owner(s) are credited and that the original publication in this journal is cited, in accordance with accepted academic practice. No use, distribution or reproduction is permitted which does not comply with these terms. 